\title{
Evaluation of the Indicators of Inflammation in Children and Adolescents with Attention Deficit and Hyperactivity Disorder: Effect of Sex and Subtype
}

\author{
Dikkat Eksikliği ve Hiperaktivite Bozukluğu Olan Çocuk ve Ergenlerde İnflamasyon \\ Göstergelerinin Değerlendirilmesi: Cinsiyet ve Alt Tipin Etkisi
}

\author{
Gülen GÜLER AKSU \\ (D) 0000-0001-9555-3916 \\ Pelin DA $\breve{G}^{2}$ \\ (D) 0000-0002-5051-3459
}

\begin{abstract}
${ }^{1}$ Mersin University Medical Faculty Department of Child and Adolescent Psychiatry, Mersin, Turkey

${ }^{2}$ Mersin City Training and Research Hospital Department of Child and
\end{abstract} Adolescent Psychiatry, Mersin, Turkey

\begin{abstract}
Aim: It was aimed to evaluate the hematological inflammatory markers in treatment-naive and comorbidity-free children and adolescents with attention deficit and hyperactivity disorder (ADHD) in this study.

Material and Methods: One hundred sixty-nine children aged 6-18, who were diagnosed with ADHD according to DSM-5 criteria were included in the study. Age and sex-matched 59 healthy children without any psychiatric and/or medical disorder were included as a control group. The children who had an intellectual disability and/or autism spectrum disorder, acute, chronic or inflammatory diseases were excluded from the study. Smoking, obesity and using psychotropic medications and lack of data in records were other exclusion criteria. ADHD and control groups were compared in terms of sociodemographic characteristics, inflammatory markers and hematological parameters.

Results: Mean platelet volume (MPV) and Basophil (BASO) levels were significantly higher in the ADHD group compared to the control group and this statistical difference was only observed for boys. In hyperactivity subtype, red cell distribution width (RDW), lymphocyte (LYMPH) and monocytes (MONO) were higher; in attention deficit subtype mean platelet volume-to-lymphocyte ratio (MPVLR) was higher than all other subtypes and control group. MPV was similar in three subtypes, and were higher in all of them than the control group.

Conclusion: This study revealed that MPV and BASO tend to be higher in the ADHD group especially in boys. Hematological biomarkers may be useful for diagnosis of ADHD and determination of ADHD subtypes but data on this subject are insufficient and more comprehensive studies are needed.
\end{abstract}

Keywords: ADHD; biomarkers; child; inflammation; sex.

ÖZ

Amaç: Bu çalışmada, tedavi almayan ve komorbiditesi olmayan dikkat eksikliği hiperaktivite bozukluğu (DEHB) tanılı çocuk ve ergenlerde hematolojik inflamatuar biyobelirteçlerin değerlendirilmesi amaçlanmıştır.

Gereç ve Yöntemler: Bu çalışmaya DSM-5 kriterlerine göre DEHB tanısı alan 6-18 yaş arası 169 çocuk dahil edildi. Yaş ve cinsiyet açısından eşleştirilmiş psikiyatrik ve/veya tıbbi hastalığı olmayan 59 sağlıklı çocuk kontrol grubu olarak alındı. Anlıksal yeti yitimi ve/veya otizm spektrum bozukluğu, akut, kronik veya inflamatuar bir hastalığı olan çocuklar çalışma dışı bırakıldı. Sigara kullanımı, obezite, psikotrop ilaçların kullanımı ve kayıt bilgilerinin yetersiz olması diğer dışlama kriterleri idi. DEHB ve kontrol grupları sosyodemografik özellikler, inflamatuar belirteçler ve hematolojik parametreler açısından karşılaştırıldı.

Bulgular: Ortalama platelet volümü (MPV) ve bazofil (BASO) düzeyleri DEHB grubunda kontrol grubuna göre anlamlı düzeyde yüksek idi ve bu fark sadece erkeklerde görüldü. Hiperaktif grupta eritrosit dağılım genişliği (RDW), lenfosit (LYMPH)ve monosit (MONO) daha yüksekti; dikkat eksikliği grubunda ortalama platelet volümü/lenfosit oranı (MPVLR) diğer tüm alt gruplardan ve kontrol grubundan daha yüksek idi. MPV ise üç alt grupta benzerdi ve bu grupların tümünde kontrol grubundan daha yüksekti.

Sonuç: Bu çalışma MPV ve BASO düzeylerinin DEHB grubunda, özellikle erkek çocuklarda daha yüksek olma eğiliminde olduğunu ortaya koymaktadır. Hematolojik biyobelirteçler DEHB tanısında ve DEHB alt tiplerinin belirlenmesinde faydalı olabilir ancak bu konudaki veriler henüz yetersizdir ve daha kapsamlı çalışmalara ihtiyaç vardır.

Accepted / Kabul Tarihi : 08.05.2020 Available Online /

Anahtar kelimeler: DEHB; biyobelirteçler; çocuk; inflamasyon; cinsiyet. 


\section{INTRODUCTION}

Attention deficit and hyperactivity disorder (ADHD) is one of the neurodevelopmental disorders of childhood (1). The estimated worldwide prevalence of ADHD is 5.3\% in children and adolescents. The frequency of ADHD declines with age but can persist into adulthood, affecting between 2.5 and $4.4 \%$ of adults (2). The prevalence of ADHD is \%12.4 in a cross-sectional multicenter nationwide study in Turkey (3). Genetic, psychological, social, biochemical and environmental factors are known to be involved in the etiology of ADHD but the etiology has not yet been fully elucidated. In addition to very strong genetic evidence, the importance of gene-environment interaction in the etiology of ADHD is emphasized (4-6). Environmental factors are thought to cause risk for ADHD by causing inflammation in the prenatal brain and decreasing gray matter volume (7).

In recent years, the interaction between the immune system and the central nervous system has been one of the most important research topics. The immune system is known to have significant effects on learning, memory and neural plasticity (8). The effect of the immune system on neurobiology of ADHD may be due to the disruption of the balance between inflammatory and anti-inflammatory mechanisms (9). In the studies increased IL-6, IL-10 (10), anti-purkinje cell antibodies (10), dopamine transporter protein autoantibodies (11), increased pro-inflammatory cytokines such as TNF- $\beta$ and decreased anti-inflammatory cytokines such as IL-2, IL-4, and INF-y (12) are some findings which indicate inflammation response in ADHD. Also, children whose mothers have immune system related diseases such as multiple sclerosis, type 1 diabetes, hypothyroidism, rheumatoid arthritis have an increased risk for ADHD (13). Inflammatory cytokines lead to ADHD by affecting prefrontal cortex maturation, neurotransmitter composition and peripheral inflammation also lead to ADHD by increasing excitability, and microglial activation through TNF- $\alpha$ (14-15).

While these inflammatory markers are investigated especially in studies, they cannot be used in clinical practice because they are expensive. Inexpensive, costeffective, easily accessible hematological markers of inflammation derived from complete blood count test such as mean platelet volume (MPV), neutrophil/lymphocyte ratio (NLR), platelet/lymphocyte ratio (PLR), red cell distribution width (RDW), mean platelet volume-tolymphocyte ratio (MPVLR) have become increasingly noticeable lately.

Although hematological markers of inflammation are studied in different psychiatric disorders, consistent data on ADHD is still insufficient. We aimed to evaluate the hematological markers of inflammation of treatment-naive and comorbidity-free children and adolescents with ADHD in this study.

\section{MATERIAL AND METHODS}

One hundred sixty-nine children aged 6-18, who admitted to Child and Adolescent Psychiatry Department of Mersin University Medical Faculty between 31.06.2018 and 31.12.2018 and diagnosed as ADHD according to Diagnostic and Statistical Manual of Mental Disorders, $5^{\text {th }}$ edition (DSM-5, 1) criteria participated in this study. Comorbid psychiatric disorders were screened and while oppositional defiant disorder (ODD) is included, all other psychiatric disorders are excluded.

Ethical approval was obtained for this study and that participation involved informed consent (Mersin University Institutional Review Board protocol approval date 23/01/2019, number 2019/39).

Exclusion criteria of the research were: 1) to have an intellectual disability and/or autism spectrum disorder according to DSM-5 criteria; 2) to have an acute, chronic or inflammatory disease; 3) smoking; 4) obesity; 5) to use psychotropic medication; and 6) to have missing data in digital system records.

The control group consisted of age and sex-matched 59 children who admitted to our clinic for advice and did not have any psychiatric disorder according to DSM-5. Sociodemographic data such as age, sex, and parental consanguinity, medical and mental psychopathology of parents, delivery time/type, and accompanying medical comorbidity were analyzed.

MPV, NLR, monocytes/lymphocyte ratio (MLR), PLR and RDW values and some other hematological parameters (hemoglobin (HGB), red blood cell (RBC), mean corpusculer volume (MCV), mean corpusculer hemoglobin $(\mathrm{MCH})$, mean corpusculer hemoglobin concentration (MCHC), platelet (PLT), etc.) calculated from complete blood count in the digital record system of our hospital.

Sociodemographic characteristics, inflammatory markers, and hematological parameters were compared between the ADHD group and the control group.

\section{Statistical Analysis}

Normality assumption of continuous variables was evaluated with the Kolmogorov-Simirnov test, while Levene test was used for homogeneity of variances. Independent samples test was used to compare two groups, while One-Way Analyze of Variance followed by Fisher LSD post hoc test was used for three or more groups. Receiver operating characteristic (ROC) curve analysis was used to determine the cut-off values for discriminate the groups. In the analysis of categorical variables, Pearson chi-square or Fisher's exact test in case of expected value less than 5 , were used. The statistical significance level was taken as 0.05 , and statistical analyses were done with SPSS v.20 statistical package.

\section{RESULTS}

This study consisted of 169 ADHD patients (39 girls, 130 boys) and 59 healthy children (11 girls, 48 boys) with a mean age of $9.68 \pm 2.98$ and $10.33 \pm 3.15$ years, respectively. There was no statistically significant difference between groups in terms of age $(\mathrm{p}=0.159)$, and sex $(\mathrm{p}=0.479)$. While the parental consanguinity was higher in the ADHD group $(\mathrm{p}=0.027)$, spontaneous vaginal delivery rate was higher in the control group $(\mathrm{p}=0.033)$ Sociodemographic characteristics and comparison of ADHD and control groups were given in Table 1.

Among inflammatory markers, MPV was found higher in the ADHD group than the control group $(\mathrm{p}<0.001)$; NLR, PLR, MLR, MPVLR did not differ between the groups. Among complete blood count parameters, only the basophil (BASO) level was higher in the ADHD group than the control group $(\mathrm{p}=0.037$, Table 2$)$. 
Table 1. Sociodemographic characteristics of ADHD and control groups

\begin{tabular}{|c|c|c|c|}
\hline & $\begin{array}{c}\text { ADHD } \\
(n=169)\end{array}$ & $\begin{array}{c}\text { Control } \\
(n=59)\end{array}$ & $\mathbf{p}$ \\
\hline Age, years & $9.68 \pm 2.98$ & $10.33 \pm 3.15$ & 0.159 \\
\hline \multicolumn{4}{|l|}{ Sex } \\
\hline Girl & $39(23.1 \%)$ & $11(18.6 \%)$ & \multirow{2}{*}{0.479} \\
\hline Boy & $130(76.9 \%)$ & $48(81.4 \%)$ & \\
\hline Mother medical disease & $19(11.2 \%)$ & $4(6.8 \%)$ & 0.327 \\
\hline Mother psychiatric disease & $13(7.7 \%)$ & $3(5.1 \%)$ & 0.573 \\
\hline Father medical disease & $10(5.9 \%)$ & $3(5.1 \%)$ & 0.999 \\
\hline Father psychiatric disease & $4(2.4 \%)$ & $1(1.7 \%)$ & 0.999 \\
\hline Parental consanguinity & $32(18.9 \%)$ & $4(6.8 \%)$ & $\mathbf{0 . 0 2 7}$ \\
\hline Spontaneous vaginal delivery & $73(43.2 \%)$ & $35(59.3 \%)$ & $\mathbf{0 . 0 3 3}$ \\
\hline \multicolumn{4}{|l|}{ Delivery Time } \\
\hline Term & $148(87.6 \%)$ & $56(94.9 \%)$ & \multirow{3}{*}{0.413} \\
\hline Preterm & $20(11.8 \%)$ & $3(5.1 \%)$ & \\
\hline Postterm & $1(0.6 \%)$ & $0(0.0 \%)$ & \\
\hline \multicolumn{4}{|l|}{ Delivery Complication } \\
\hline Absent & $160(94.7 \%)$ & $58(98.3 \%)$ & \multirow{4}{*}{0.724} \\
\hline Breech delivery & $1(0.6 \%)$ & $0(0.0 \%)$ & \\
\hline Cord entanglement & $4(2.4 \%)$ & $0(0.0 \%)$ & \\
\hline Meconium aspiration & $4(2.4 \%)$ & $1(1.7 \%)$ & \\
\hline
\end{tabular}

ADHD: attention deficit and hyperactivity disorder

Table 2. Complete blood count parameters and inflammatory markers of ADHD and control groups

\begin{tabular}{|c|c|c|c|}
\hline & $\begin{array}{l}\text { ADHD } \\
(n=169)\end{array}$ & $\begin{array}{c}\text { Control } \\
(n=59)\end{array}$ & $\mathbf{p}$ \\
\hline $\mathrm{HGB}(\mathrm{g} / \mathrm{dl})$ & $12.85 \pm 0.99$ & $12.97 \pm 1.16$ & 0.446 \\
\hline $\operatorname{HCT}(\%)$ & $37.88 \pm 3.75$ & $36.95 \pm 5.19$ & 0.143 \\
\hline MCV (fL) & $78.11 \pm 4.79$ & $77.98 \pm 5.74$ & 0.874 \\
\hline $\mathrm{MCH}(\mathrm{pg})$ & $26.79 \pm 4.60$ & $26.82 \pm 2.51$ & 0.967 \\
\hline $\mathrm{MCHC}(\mathrm{gHb} / \mathrm{dl})$ & $33.86 \pm 1.29$ & $34.26 \pm 1.45$ & 0.064 \\
\hline RDW (\%) & $13.22 \pm 1.03$ & $13.48 \pm 1.26$ & 0.113 \\
\hline PDW (fL) & $11.75 \pm 1.92$ & $11.51 \pm 1.97$ & 0.429 \\
\hline MPV (fL) & $10.25 \pm 0.92$ & $9.65 \pm 1.01$ & $<0.001$ \\
\hline WBC $\left(10^{3} / \mathrm{uL}\right)$ & $7.79 \pm 2.18$ & $7.71 \pm 2.01$ & 0.804 \\
\hline $\operatorname{RBC}\left(10^{6} / \mathrm{uL}\right)$ & $4.95 \pm 0.83$ & $4.87 \pm 0.43$ & 0.466 \\
\hline $\operatorname{PLT}\left(10^{3} / \mathrm{uL}\right)$ & $328.05 \pm 71.60$ & $332.02 \pm 87.56$ & 0.731 \\
\hline NEUT $\left(10^{3} / \mathrm{uL}\right)$ & $3.87 \pm 1.66$ & $3.85 \pm 1.52$ & 0.916 \\
\hline LYMPH (10³/uL) & $3.00 \pm 0.93$ & $3.01 \pm 1.03$ & 0.925 \\
\hline MONO (103/uL) & $0.61 \pm 0.20$ & $0.59 \pm 0.17$ & 0.545 \\
\hline $\mathrm{EO}\left(10^{3} / \mathrm{uL}\right)$ & $0.25 \pm 0.19$ & $0.24 \pm 0.18$ & 0.526 \\
\hline $\operatorname{BASO}\left(10^{3} / \mathrm{uL}\right)$ & $0.06 \pm 0.08$ & $0.04 \pm 0.03$ & 0.037 \\
\hline NLR & $1.39 \pm 0.75$ & $1.38 \pm 0.65$ & 0.864 \\
\hline PLR & $117.06 \pm 34.40$ & $118.19 \pm 45.85$ & 0.842 \\
\hline MLR & $0.22 \pm 0.09$ & $0.21 \pm 0.10$ & 0.732 \\
\hline MPVLR & $3.75 \pm 1.22$ & $3.56 \pm 1.23$ & 0.312 \\
\hline \multicolumn{4}{|c|}{$\begin{array}{l}\text { ADHD: attention deficit and hyperactivity disorder, HGB: hemoglobin, HCT: } \\
\text { hematocrit, MCV: mean corpuscular volume; MCH: mean corpuscular hemoglobin, } \\
\text { MCHC: man corpuscular hemoglobin concentration, RDW: red cell distribution } \\
\text { width, PDW: platelet distribution width, MPV: mean platelet volume, WBC: white } \\
\text { blood cell, RBC: red blood cell, PLT: platelet, NEUT: neutrophil, LYMPH: } \\
\text { lymphocyte, MONO: monocytes, EO: eosinophils, BASO: basophils, NLR: } \\
\text { neutrophil-to-lymphocyte ratio, PLR: platelet-to-lymphocyte ratio, MLR: } \\
\text { monocytes-to-lymphocyte ratio, MPVLR: mean platelet volume-to-lymphocyte } \\
\text { ratio }\end{array}$} \\
\hline
\end{tabular}

MPV $(p<0.001)$ and BASO $(p=0.013)$ were significantly higher in boys of ADHD group than in boys of the control group, but these markers did not differ significantly in girl patients (Table 3 ).

Table 3. Complete blood count parameters and inflammatory markers of ADHD and control groups

\begin{tabular}{|c|c|c|c|c|}
\hline & Sex & $\begin{array}{l}\text { ADHD } \\
(n=169)\end{array}$ & $\begin{array}{c}\begin{array}{c}\text { Control } \\
(n=59)\end{array} \\
\end{array}$ & $\mathbf{p}$ \\
\hline \multirow{2}{*}{$\operatorname{HGB}(\mathrm{g} / \mathrm{dl})$} & Girl & $12.78 \pm 1.00$ & $12.63 \pm 1.28$ & 0.673 \\
\hline & Boy & $12.87 \pm 0.99$ & $13.05 \pm 1.12$ & 0.309 \\
\hline \multirow{2}{*}{$\operatorname{HCT}(\%)$} & Girl & $37.88 \pm 2.62$ & $35.15 \pm 7.03$ & 0.234 \\
\hline & Boy & $37.88 \pm 4.04$ & $37.37 \pm 4.66$ & 0.470 \\
\hline \multirow{2}{*}{ MCV (fL) } & Girl & $79.59 \pm 3.84$ & $76.35 \pm 9.26$ & 0.281 \\
\hline & Boy & $77.66 \pm 4.97$ & $78.36 \pm 4.66$ & 0.398 \\
\hline \multirow{2}{*}{$\mathrm{MCH}$ (pg) } & Girl & $26.89 \pm 1.79$ & $25.74 \pm 3.95$ & 0.364 \\
\hline & Boy & $26.76 \pm 5,16$ & $27.07 \pm 2.03$ & 0.691 \\
\hline \multirow{2}{*}{$\mathrm{MCHC}(\mathrm{gHb} / \mathrm{dl})$} & Girl & $33.79 \pm 1.07$ & $33.38 \pm 1.49$ & 0.315 \\
\hline & Boy & $33.88 \pm 1.36$ & $34.46 \pm 1.38$ & 0.013 \\
\hline \multirow{2}{*}{ RDW (\%) } & Girl & $13.03 \pm 0.95$ & $13.53 \pm 1.91$ & 0.421 \\
\hline & Boy & $13.27 \pm 1.05$ & $13.47 \pm 1.08$ & 0.275 \\
\hline \multirow{2}{*}{ PDW (fL) } & Girl & $11.78 \pm 1.96$ & $12.39 \pm 2.02$ & 0.372 \\
\hline & Boy & $11.74 \pm 1.92$ & $11.32 \pm 1.93$ & 0.195 \\
\hline \multirow{2}{*}{ MPV (fL) } & Girl & $10.33 \pm 0.96$ & $10.15 \pm 1.10$ & 0.585 \\
\hline & Boy & $10.22 \pm 0.91$ & $9.54 \pm 0.97$ & $<0.001$ \\
\hline \multirow{2}{*}{ WBC $\left(10^{3} / \mathrm{uL}\right)$} & Girl & $8.12 \pm 2.15$ & $8.02 \pm 2.41$ & 0.891 \\
\hline & Boy & $7.69 \pm 2.19$ & $7.64 \pm 1.93$ & 0.886 \\
\hline \multirow{2}{*}{$\mathrm{RBC}\left(10^{6} / \mathrm{uL}\right)$} & Girl & $5.02 \pm 1.55$ & $4.96 \pm 0.35$ & 0.903 \\
\hline & Boy & $4.93 \pm 0.42$ & $4.84 \pm 0.44$ & 0.253 \\
\hline \multirow{2}{*}{$\operatorname{PLT}\left(10^{3} / \mathrm{uL}\right)$} & Girl & $331.36 \pm 65.63$ & $337.36 \pm 82.16$ & 0.801 \\
\hline & Boy & $327.06 \pm 73.51$ & $330.79 \pm 89.54$ & 0.778 \\
\hline \multirow{2}{*}{$\operatorname{NEUT}\left(10^{3} / \mathrm{uL}\right)$} & Girl & $4.21 \pm 1.84$ & $4.42 \pm 1.77$ & 0.743 \\
\hline & Boy & $3.77 \pm 1.60$ & $3.72 \pm 1.45$ & 0.835 \\
\hline \multirow{2}{*}{ LYMPH $\left(10^{3} / \mathrm{uL}\right)$} & Girl & $2.93 \pm 1.02$ & $2.72 \pm 0.85$ & 0.534 \\
\hline & Boy & $3.02 \pm 0.91$ & $3.08 \pm 1.06$ & 0.708 \\
\hline \multirow{2}{*}{ MONO $\left(10^{3} / \mathrm{uL}\right)$} & Girl & $0.63 \pm 0.19$ & $0.56 \pm 0.15$ & 0.274 \\
\hline & Boy & $0.60 \pm 0.20$ & $0.59 \pm 0.18$ & 0.892 \\
\hline \multirow{2}{*}{$\mathrm{EO}\left(10^{3} / \mathrm{uL}\right)$} & Girl & $0.25 \pm 0.23$ & $0.20 \pm 0.21$ & 0.549 \\
\hline & Boy & $0.26 \pm 0.18$ & $0.24 \pm 0.18$ & 0.694 \\
\hline \multirow{2}{*}{$\operatorname{BASO}\left(10^{3} / \mathrm{uL}\right)$} & Girl & $0.07 \pm 0.14$ & $0.03 \pm 0.02$ & 0.413 \\
\hline & Boy & $0.05 \pm 0.05$ & $0.04 \pm 0.03$ & 0.013 \\
\hline \multirow{2}{*}{ NLR } & Girl & $1.59 \pm 0.84$ & $1.73 \pm 0.75$ & 0.634 \\
\hline & Boy & $1.34 \pm 0.72$ & $1.30 \pm 0.61$ & 0.733 \\
\hline \multirow{2}{*}{ PLR } & Girl & $122.30 \pm 34.01$ & $135.39 \pm 58.93$ & 0.349 \\
\hline & Boy & $115.48 \pm 34.48$ & $114.25 \pm 42.08$ & 0.843 \\
\hline \multirow{2}{*}{ MLR } & Girl & $0.23 \pm 0.09$ & $0.22 \pm 0.10$ & 0.717 \\
\hline & Boy & $0.21 \pm 0.09$ & $0.21 \pm 0.10$ & 0.903 \\
\hline \multirow{2}{*}{ MPVLR } & Girl & $3.95 \pm 1.40$ & $4.13 \pm 1.49$ & 0.706 \\
\hline & Boy & $3.69 \pm 1.16$ & $3.43 \pm 1.14$ & 0.186 \\
\hline
\end{tabular}

ADHD: attention deficit and hyperactivity disorder, HGB: hemoglobin, HCT: hematocrit, MCV: mean corpuscular volume; $\mathrm{MCH}$ : mean corpuscular hemoglobin, MCHC: mean corpuscular hemoglobin concentration, RDW: red cell distribution width, PDW: platelet distribution width, MPV: mean platelet volume, WBC: white blood cell, RBC: red blood cell, PLT: platelet, NEUT: neutrophil, LYMPH: lymphocyte, MONO: monocytes, EO: eosinophils, BASO: basophils, NLR: neutrophil-to-lymphocyte ratio, PLR: platelet-to-lymphocyte ratio, MLR: monocytes-to-lymphocyte ratio, MPVLR: mean platelet volume-to-lymphocyte ratio 
When ADHD subtypes and control group were compared, statistically significant differences were detected in terms of RDW $\quad(\mathrm{p}=0.003), \quad \mathrm{LYMPH} \quad(\mathrm{p}=0.016), \quad \mathrm{MONO}$ $(\mathrm{p}=0.048), \operatorname{MPV}(\mathrm{p}<0.001)$ and MPVLR $(\mathrm{p}=0.004)$. According to the results of post hoc analyses RDW, LYMPH and MONO were higher in hyperactivity subtype than all other subtypes and control group, while MPV was similar in three subtype and three of them were higher than control group. Besides, MPVLR was higher in attention deficit subtype than all other subtypes and control group (Table 4).

ROC curve analysis was performed to assess the diagnostic value of MPV and BASO (Figure 1). The area under the curve for MPV was $0.662(95 \% \mathrm{CI}, 0.581$ to $0.742, \mathrm{p}<0.001$ ), and a significant but weak cut off value was 9.75 , with a sensitivity of $71.6 \%$ and specificity of $55.9 \%$, respectively. The area under the curve for BASO was 0.656 (95\% CI, 0.596 to $0.744, \mathrm{p}<0.001)$ with a significant but weak cut-off value of 0.04 with a sensitivity of $70.4 \%$ and a specificity of $54.2 \%$, respectively.

\section{DISCUSSION}

This study on the usability of hematological parameters as inflammatory markers obtained from the complete blood count indicated that MPV and BASO were significantly

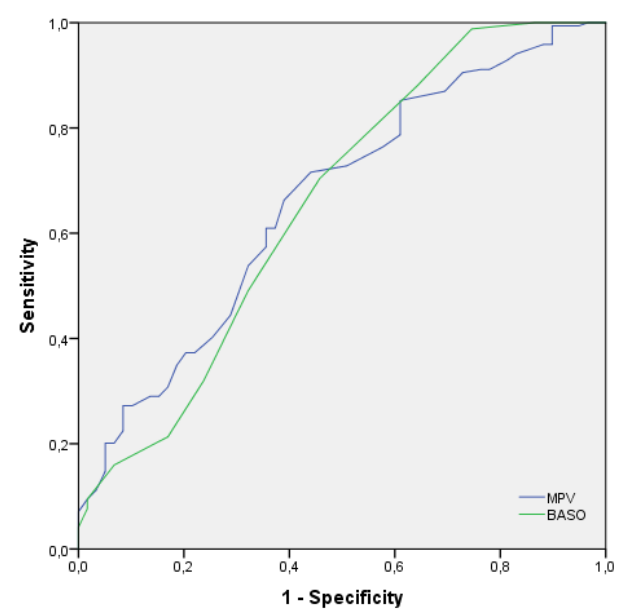

Figure 1. ROC curve analysis performed to assess the diagnostic value of MPV and BASO higher in the ADHD group compared to the control group and this difference was only valid for boys. This study indicated that RDW and MONO could be differentiating parameters for hyperactivity subtype and MPVLR for attention-deficit subtype.

Although there are studies in the literature on inflammatory hematological markers in ADHD, there is no study examining these markers according to sex and ADHD subtypes. There are different results in the studies investigating the relationship between ADHD and inflammation in the literature.

In cytokine studies, IL-6 levels were found to be higher in ADHD patients, but not correlated with ADHD severity (16). In another study, IL-6, IL-10, and anti-YO antibodies reported to be significantly higher in ADHD (10). On contrary to these findings, it suggested that ADHD symptomatology is not associated with pro-inflammatory cytokines such as IL-6, TNF-alpha and BDNF (17). Studies are on the rise about easy, inexpensive and suitable for routine use methods calculated from complete blood count parameters instead of expensive ones such as interleukins. MPV, NLR, PLR, RDW, MPVLR are hematological indicators predicting inflammation (18-20). These parameters obtained through a simple blood count, such as a hemogram, are shown as new markers in the evaluation of systemic inflammatory response.

MPV is a widely used marker that correlates with the platelet function and activation of inflammatory conditions (21). In a study on platelet and MPV levels in ADHD, MPV found to be higher than controls, but no difference found in platelet levels (22).

There are some studies which indicate NLR as an inflammatory marker can increase in depression, bipolar disorder and schizophrenia $(19,23-26)$. PLR is a sensitive inflammatory marker and prognostic factor in some malignancies (27). While some studies showed that PLR increased in ADHD, some studies did not show any significant changes $(19,23)$. RDW indicates the change in size and volume of red blood cells. Inflammatory and infectious conditions lead to an increase in RDW due to the peripheral flow of premature reticulocytes. It is associated with chronic inflammatory conditions rather than acute inflammation (28). There is not enough knowledge about RDW and MPVLR levels about ADHD in the literature.

Table 4. Complete blood count parameters and inflammatory markers in ADHD subtypes

\begin{tabular}{lccccc}
\hline & Attention deficit & Hyperactivity & Combined & Control & p \\
\hline RDW $(\%)$ & $13.16 \pm 0.92^{\mathrm{a}}$ & $14.68 \pm 2.19^{\mathrm{b}}$ & $13.16 \pm 0.94^{\mathrm{a}}$ & $13.48 \pm 1.26^{\mathrm{a}}$ & $\mathbf{0 . 0 0 3}$ \\
MPV (fL) & $10.50 \pm 0.74^{\mathrm{a}}$ & $10.37 \pm 1.21^{\mathrm{a}}$ & $10.18 \pm 0.94^{\mathrm{a}}$ & $9.65 \pm 1.01^{\mathrm{b}}$ & $<\mathbf{0 . 0 0 1}$ \\
LYMPH $\left(10^{3} / \mathrm{uL}\right)$ & $2.70 \pm 0.94^{\mathrm{a}}$ & $4.02 \pm 1.22^{\mathrm{b}}$ & $3.02 \pm 0.88^{\mathrm{a}}$ & $3.01 \pm 1.03^{\mathrm{a}}$ & $\mathbf{0 . 0 1 6}$ \\
MONO $\left(10^{3} / \mathrm{uL}\right)$ & $0.58 \pm 0.16^{\mathrm{a}}$ & $0.81 \pm 0.29^{\mathrm{b}}$ & $0.60 \pm 0.20^{\mathrm{a}}$ & $0.59 \pm 0.17^{\mathrm{a}}$ & $\mathbf{0 . 0 4 8}$ \\
NLR & $1.60 \pm 0.87$ & $0.97 \pm 0.37$ & $1.36 \pm 0.73$ & $1.38 \pm 0.65$ & 0.179 \\
PLR & $124.50 \pm 37.93$ & $107.07 \pm 53.84$ & $115.63 \pm 32.41$ & $118.19 \pm 45.85$ & 0.587 \\
MLR & $0.24 \pm 0.11$ & $0.21 \pm 0.07$ & $0.21 \pm 0.08$ & $0.21 \pm 0.10$ & 0.491 \\
MPVLR & $4.31 \pm 1.39^{\mathrm{a}}$ & $2.70 \pm 0.54^{\mathrm{b}}$ & $3.66 \pm 1.14^{\mathrm{b}}$ & $3.56 \pm 1.23^{\mathrm{b}}$ & $\mathbf{0 . 0 0 4}$ \\
\hline
\end{tabular}

ADHD: attention deficit and hyperactivity disorder, RDW: red cell distribution width, MPV: mean platelet volume, LYMPH: lymphocyte, MONO: monocytes, NLR: neutrophil-to-lymphocyte ratio, PLR: platelet-to-lymphocyte ratio, MLR: monocytes-to-lymphocyte ratio, MPVLR: mean platelet volume-to-lymphocyte ratio, a,b,c: different superscript letters denote significant differences between the groups according to the results of post hoc tests 
In high grade inflammatory disease, MPV levels negatively correlated with inflammation (29-31) however, MPV levels found to be increased in low grade inflammatory diseases such as embolism and infective endocarditis (21,32). MPV was also investigated in psychiatric disorders such as bipolar disorder, depression, anxiety disorder, panic disorder, suicide attempt, and ADHD (23,33-36). In this study, MPV and BASO levels were found to be high, especially in boys, but no significant difference was observed in other inflammatory and hematological markers. The exclusion of medical and psychiatric comorbidities except for ODD reinforces the relationship between ADHD and current findings. Although similar findings found in the literature, there are also opposite studies. Yorbik et al. (22) reported increased MPV as an indicator of the inflammatory response in ADHD. Avcil et al. (19) found MPV, NLR, and PLR levels were higher than the controls, Binici et al. (23) reported only MPV levels were higher in ADHD compared to the control group but this difference was not significant in the analyses performed with comorbidity and body mass index. In our study, we excluded all psychiatric disorders and obese patients except ODD and so body mass index was not evaluated as a cofactor.

In the literature, there is no information about the relationship between BASO levels and ADHD. In this respect, this study presents new information. ADHD is associated with allergic diseases such as asthma, allergic rhinitis and atopic dermatitis. The immune response to these allergic diseases are known to increase the risk of neurodevelopmental diseases by affecting the central nervous system $(37,38)$. In a study about allergic disease and inflammation in ADHD, allergic diseases, Ig-E and eosinophil levels were higher in the ADHD group (39). In this study, there was no difference in eosinophil levels, but basophil levels were significantly higher in the ADHD group than in the control group. Eosinophil values in the normal range may be due to the exclusion of diseases such as comorbid asthma and allergy from this study.

Peripheral basophilia is known to be able to associate with allergic diseases. Although the mechanism of action of basophils is not known clearly, basophils are divided into two categories as thymic stromal lymphopoietin elicited basophil and IL-3 elicited basophil. Thymic stromal lymphopoietin elicited basophils are Ig-E independent, IL3 elicited basophil have Ig-E dependent effect. Allergy mechanisms similarly classified as Ig-E dependent and independent (40). Although allergic diseases excluded from our study group, increased basophil levels found in the ADHD group. This suggests there may be a subclinical allergic inflammation in the etiopathogenesis of ADHD and BASO may be a marker for ADHD. There is a need for comprehensive studies on this subject.

There is no study showing RDW as an inflammatory marker in ADHD. In only one study about nutrient intake and hematological parameters in ADHD, only RDW levels were higher in the ADHD group without treatment compared to the ADHD in the treatment and control group (41). In our study, no difference found between the ADHD and the control group in RDW level, whereas RDW was significantly higher in the ADHD hyperactivity subtype than the other subtypes. RDW may be a significant marker for the differentiation of subtypes. Similarly, MONO levels for hyperactivity subtype and MPVLR for attentiondeficit subtype may be a significant marker. In the literature, MONO levels did not differ between ADHD and controls, and did not investigate in ADHD subtypes (23). Another marker, MPVLR is a strong predictor of diabetic nephropathy (42), in the diagnosis of childhood appendicitis and the differentiation of appendicitis perforation (43) and early and late mortality in ST elevated myocardial infarction (44). While there are studies on MPVLR in different diseases, no studies found in psychiatric diseases.

This study has several limitations. First; it was designed as a retrospective and cross-sectional study. The causality relationship cannot establish because of the design of the study. Second; we did not evaluate other inflammatory markers such as cytokines in combination with these parameters. Third, we did not evaluate the severity of ADHD. So we could not see the variability of these parameters according to ADHD severity. On the other hand, there are many strengths of this study. The study groups consisted of newly diagnosed patients who do not use any medication and do not have any medical or psychiatric comorbidities except ODD.

\section{CONCLUSION}

To our knowledge, it is the first study evaluating the hematological inflammatory markers according to sex and ADHD subtypes. This study reveals that MPV and BASO tend to be higher in the ADHD group, especially in boys. Our findings suggest RDW, MONO and MPVLR may be a marker for the differentiation of subtypes. This study indicated the need for prospective study with a larger sample on complete blood count parameters in ADHD by sex and subtype.

\section{REFERENCES}

1. American Psychiatric Association. Diagnostic and statistical manual of mental disorders. $5^{\text {th }} \mathrm{ed}$. Arlington, VA: American Psychiatric Association; 2013.

2. Sharp SI, McQuillin A, Gurling HMD. Genetics of attention-deficit hyperactivity disorder (ADHD). Neuropharmacology. 2009;57(7-8):590-600.

3. Ercan ES, Polanczyk G, Akyol Ardic U, Yuce D, Karacetin G, Tufan AE, et al. The prevalence of childhood psychopathology in Turkey: a crosssectional multicenter nationwide study (EPICPAT-T). Nord J Psychiatry. 2019;73(2):132-40.

4. Paloyelis Y, Rijsdijk F, Wood AC, Asherson P, Kuntsi J. The genetic association between ADHD symptoms and reading difficulties: the role of inattentiveness and IQ. J Abnorm Child Psychol. 2010;38(8):1083-95.

5. Thapar A, Cooper M, Jefferies R, Stergiakouli E. What causes attention deficit hyperactivity disorder? Arch Dis Child. 2012;97(3):260-5.

6. van den Berg SM, Willemsen G, de Geus EJC, Boomsma DI. Genetic etiology of stability of attention problems in young adulthood. Am J Med Genet Part B Neuropsychiatr Genet. 2006;141B(1):55-60.

7. Dunn GA, Nigg JT, Sullivan EL. Neuroinflammation as a risk factor for attention deficit hyperactivity disorder. Pharmacol Biochem Behav. 2019;182:22-34.

8. Yirmiya R, Goshen I. Immune modulation of learning, memory, neural plasticity and neurogenesis. Brain 
Behav Immun. 2011;25(2):181-213.

9. Leffa DT, Torres ILS, Rohde LA. A Review on the role of inflammation in attention-deficit/hyperactivity disorder. Neuroimmunomodulation. 2018;25(5-6):328-33.

10. Donfrancesco R, Nativio P, Di Benedetto A, Villa MP, Andriola E, Melegari MG, et al. Anti-yo antibodies in children with ADHD: First results about serum cytokines. J Atten Disord. 2016;108705471664338.

11. Giana G, Romano E, Porfirio MC, D’Ambrosio R, Giovinazzo S, Troianiello M, et al. Detection of autoantibodies to DAT in the serum: Interactions with DAT genotype and psycho-stimulant therapy for ADHD. J Neuroimmunol. 2015;278:212-22.

12. Verlaet AAJ, Noriega DB, Hermans N, Savelkoul HFJ. Nutrition, immunological mechanisms and dietary immunomodulation in ADHD. Eur Child Adolesc Psychiatry. 2014;23(7):519-29.

13. Instanes JT, Halmøy A, Engeland A, Haavik J, Furu K, Klungsøyr K. Attention-deficit/hyperactivity disorder in offspring of mothers with inflammatory and immune system diseases. Biol Psychiatry. 2017;81(5):452-9.

14. Buske-Kirschbaum A, Schmitt J, Plessow F, Romanos M, Weidinger S, Roessner V. Psychoendocrine and psychoneuroimmunological mechanisms in the comorbidity of atopic eczema and attention deficit/hyperactivity disorder. Psychoneuroendocrinology. 2013;38(1):12-23.

15. Riazi K, Galic MA, Kuzmiski JB, Ho W, Sharkey KA, Pittman QJ. Microglial activation and TNF $\alpha$ production mediate altered CNS excitability following peripheral inflammation. Proc Natl Acad Sci USA. 2008;105(44):17151-6.

16. Darwish AH, Elgohary TM, Nosair NA. Serum interleukin-6 level in children with attention-deficit hyperactivity disorder (ADHD). J Child Neurol. 2019;34(2):61-7.

17. Vogel SWN, Bijlenga D, Verduijn J, Bron TI, Beekman ATF, Kooij JJS, et al. Attentiondeficit/hyperactivity disorder symptoms and stressrelated biomarkers. Psychoneuroendocrinology. 2017;79:31-9.

18. Hao X, Li D, Wu D, Zhang N. The relationship between hematological indices and autoimmune rheumatic diseases (ARDs), a meta-analysis. Sci Rep. 2017;7(1):10833.

19. Avcil S. Evaluation of the neutrophil/lymphocyte ratio, platelet/lymphocyte ratio, and mean platelet volume as inflammatory markers in children with attention-deficit hyperactivity disorder. Psychiatry Clin Neurosci. 2018;72(7):522-30.

20. Özer S, Yılmaz R, Sönmezgöz E, Karaaslan E, Taşkın S, Bütün İ, et al. Simple markers for subclinical inflammation in patients with familial mediterranean fever. Med Sci Monit. 2015;21:298-303.

21. Gasparyan AY, Ayvazyan L, Mikhailidis DP, Kitas GD. Mean platelet volume: a link between thrombosis and inflammation? Curr Pharm Des. 2011;17(1):47-58.

22. Yorbik O, Mutlu C, Tanju IA, Celik D, Ozcan O. Mean platelet volume in children with attention deficit hyperactivity disorder. Med Hypotheses. 2014;82(3):341-5.

23. Binici NC, Kutlu A. Is ADHD an inflammation-related disorder? Anadolu Psikiyatri Derg. 2019;20(3):313-20.
24. Uçar HN, Eray Ş, Murat D. Simple peripheral markers for inflammation in adolescents with major depressive disorder. Psychiat Clin Psych. 2018;28(3):254-60.

25. Semiz M, Yildirim O, Canan F, Demir S, Hasbek E, Tuman TC, et al. Elevated neutrophil/lymphocyte ratio in patients with schizophrenia. Psychiatr Danub. 2014;26(3):220-5.

26. Giynas Ayhan M, Cicek IE, Inanli I, Caliskan AM, Kirci Ercan S, Eren I. Neutrophil/lymphocyte and platelet/lymphocyte ratios in all mood states of bipolar disorder. Psychiat Clin Psych. 2017;27(3):278-82.

27. Proctor MJ, Morrison DS, Talwar D, Balmer SM, Fletcher CD, O'Reilly DS, et al. A comparison of inflammation-based prognostic scores in patients with cancer. A Glasgow inflammation outcome study. Eur J Cancer. 2011;47(17):2633-41.

28. Demircan F, Gözel N, Kılınç F, Ulu R, Atmaca M. The impact of red blood cell distribution width and neutrophil/lymphocyte ratio on the diagnosis of major depressive disorder. Neurol Ther. 2016;5(1):27-33.

29. Yüksel O, Helvaci K, Başar O, Köklü S, Caner S, Helvaci N, et al. An overlooked indicator of disease activity in ulcerative colitis: mean platelet volume. Platelets. 2009;20(4):277-81.

30. Safak S, Uslu AU, Serdal K, Turker T, Sonar S, Lutfi A. Association between mean platelet volume levels and inflammation in SLE patients presented with arthritis. Afr Health Sci. 2015;14(4):919-24.

31. Tanju C, Ekrem G, Berksoy Emel A, Nur A. Mean platelet volume as a negative marker of inflammation in children with rotavirus gastroenteritis. Iran J Pediatr. 2014;24(5):617-22.

32. İleri M, Kanat S, Orhan G, Türker Bayır P, Gürsoy HT, Şahin D, et al. Increased mean platelet volume in patients with infective endocarditis and embolic events. Cardiol J. 2015;22(1):37-43.

33. Mert DG, Terzi H. Mean platelet volume in bipolar disorder: The search for an ideal biomarker. Neuropsychiatr Dis Treat. 2016;12:2057-62.

34. Bondade S, Supriya, Seema HS, Shivakumar BK. Mean platelet volume in depression and anxiety disorder- a hospital based case-control study. Int Neuropsychiatr Dis J. 2018;11(4):1-8.

35. Orum MH, Kara MZ, Egilmez OB. Mean platelet volume and neutrophil to lymphocyte ratio as parameters to indicate the severity of suicide attempt. J Immunoass Immunochem. 2018;39(6):647-59.

36. Asoglu M, Aslan M, Imre O, Kivrak Y, Akil O, Savik E, et al. Mean platelet volume and red cell distribution width levels in initial evaluation of panic disorder. Neuropsychiatr Dis Treat. 2016;12:2435-8.

37. Yang CF, Yang CC, Wang IJ. Association between allergic diseases, allergic sensitization and attentiondeficit/hyperactivity disorder in children: A largescale, population-based study. J Chinese Med Assoc. 2018;81(3):277-83.

38. Chang HY, Seo JH, Kim HY, Kwon JW, Kim BJ, Kim $\mathrm{HB}$, et al. Allergic diseases in preschoolers are associated with psychological and behavioural problems. Allergy Asthma Immunol Res. 2013;5(5):315-21.

39. Wang LJ, Yu YH, Fu ML, Yeh WT, Hsu JL, Yang YH, et al. Attention deficit-hyperactivity disorder is 
associated with allergic symptoms and low levels of hemoglobin and serotonin. Sci Rep. 2018;8(1):10229.

40. Siracusa MC, Kim BS, Spergel JM, Artis D. Basophils and allergic inflammation. J Allergy Clin Immunol. 2013;132(4):789-801.

41. Menegassi M, de Mello ED, Guimarães LR, Matte BC, Driemeier F, Pedroso GL, et al. Food intake and serum levels of iron in children and adolescents with attention-deficit/hyperactivity disorder. Braz J Psychiatry. 2010;32(2):132-8.

42. Kocak MZ, Aktas G, Erkus E, Duman TT, Atak BM, Savli H. Mean platelet volume to lymphocyte ratio as a novel marker for diabetic nephropathy. J Coll Physicians Surg Pak. 2018;28(11):844-7.

43. Bozlu G, Akar A, Durak F, Kuyucu N. Role of mean platelet volume-to-lymphocyte ratio in the diagnosis of childhood appendicitis. Arch Argent Pediatr. 2019;117(6):375-80.

44. Hudzik B, Szkodziński J, Lekston A, Gierlotka M, Poloński L, Gąsior M. Mean platelet volume-tolymphocyte ratio: a novel marker of poor short- and long-term prognosis in patients with diabetes mellitus and acute myocardial infarction. $\mathrm{J}$ Diabetes Complications. 2016;30(6):1097-102. 